\title{
Perspectives to Combat Microbial Resistance
}

\section{André L.S. Santos*}

Laboratório de Investigação de Peptidases, Departamento de Microbiologia Geral, Instituto de Microbiologia Paulo de Góes, and Programa de Pós-Graduação em Bioquímica, Instituto de Química, Universidade Federal do Rio de Janeiro, Brazil

\begin{abstract}
Microbial infectious diseases continue to be one of the greatest health problems worldwide, afflicting millions of people annually. Due to the diminutive arsenal of efficient antimicrobial agents and the frequent appearance of resistance to the drugs in current use, which consequently reduce the means to treat infected patients, there is a very urgent and continuous need to develop new chemotherapeutic drugs. This paper presents a personal opinion on this theme and some beneficial examples obtained and published by my research group along the last five years.
\end{abstract}

Keywords: Microbial resistance; Alternative chemotherapy; Antimicrobial drugs; Microbial targets; New antimicrobial strategies.

\section{Opinion}

A major global concern is the emergence and spread of systemic life-threatening microbial infections, particularly in critically ill patients [1-7]. Furthermore, the resistance to antimicrobial drugs has become a topical and alarming problem that culminates in longer period of hospitalization, increases in the financial cost and severe morbimortality outcomes, which constitute a real socioeconomic issue all over the world [8-10]. The development of new potent antimicrobial drugs is becoming more challenging every day since current drugs either have too many side-effects or they tend to lose effectiveness due to the emergence of resistant microbial strains [11-13]. In view of this alarming scenario, a number of different strategies have emerged, including (i) detection of new microbial targets, (ii) synthesis of bioactive compounds presenting new mechanisms of action, (iii) search for new compounds from different environmental sources, (iv) drug repurposing, and (v) combined therapy with synergistic effect [14-23].

Microbial proteases have emerged as potential targets for the development of novel antimicrobial chemotherapeutics, since this class of hydrolytic enzymes is directly implicated in several facets of basic biological processes as well as in numerous events of interaction between microorganisms and host structures [24-26]. In this way, our research group showed that aspartic protease inhibitors commonly used in the anti-human immunodeficiency virus therapy were able to (i) inhibit the hydrolytic activity of aspartic-type proteases, (ii) arrest crucial physiological events (e.g., nutrition, proliferation, growth and differentiation), (iii) induce morphological and ultrastructural alterations, and (iv) block the expression of virulence attributes linked to the infective process in distinct classes of microorganisms, such as yeasts (e.g., Candida albicans, Candida parapsilosis and Cryptococcus neoformans), filamentous fungi (e.g., Fonsecaea pedrosoi) and protozoa (e.g., Leishmania amazonensis and Trypanosoma cruzi), which culminated in the blockage of adhesion to both abiotic (e.g., plastic and glass) and biotic (e.g., mammalian cells) surfaces as well as in the increased susceptibility to killing by phagocytic cells [27-43].

Metal-based chemotherapeutic drugs are widely documented as powerful antimicrobial agents [44-46]. Corroborating this statement, a few metal-based drugs are already available in clinical arena, and others are currently being developed [47-49]. In this context, our group in collaboration to Irish researchers leaded by Dr. Malachy McCann (Chemistry Department, National University of Ireland), Michael Devereux (The Inorganic Pharmaceutical and Biomimetic Research
Centre, Focas Research Institute, Dublin Institute of Technology) and Andrew Kellett (School of Chemical Sciences and the National Institute for Cellular Biotechnology, Dublin City University) have demonstrated that the coordination of 1,10-phenanthroline-5,6-dione (phendione), an heteroaromatic derivative of phenanthrene, to silver $\left(\mathrm{Ag}^{+}\right)$or copper $\left(\mathrm{Cu}^{2+}\right)$ ions represents a new promising group of anti-infective agents, which revealed a potent anti-Pseudomonas aeruginosa action against both planktonic- and biofilm-growing cells [50].

The high morbidity and mortality associated with microbial infections is compounded by the limited therapeutic options and the emergence of drug-resistant strains. In parallel, the pharmaceutical companies are losing interest in new antimicrobial development. In this context, the researchers around the world will have a central and crucial mission to overcome this eminent dilemma, for example, helping in the proposition of novel practice and cheap solutions to solve this public concern.

\section{References}

1. Sydnor ER, Perl TM (2011) Hospital epidemiology and infection control in acute-care settings. Clin Microbiol Rev 24: 141-173.

2. Tanwar J, Das S, Fatima Z, Hameed S (2014) Multidrug resistance: an emerging crisis. Interdiscip Perspect Infect Dis 2014: 541340.

3. Guidry CA, Mansfield SA, Sawyer RG, Cook CH (2014) Resistant pathogens, fungi, and viruses. Surg Clin North Am 94: 1195-1218.

4. Balsalobre LC, Dropa M, Matté MH (2014) An overview of antimicrobial resistance and its public health significance. Braz J Microbiol 45: 1-5.

5. Köhler JR, Casadevall A, Perfect J (2014) The spectrum of fungi that infects humans. Cold Spring Harb Perspect Med 5: a019273.

6. Badiee P, Hashemizadeh Z (2014) Opportunistic invasive fungal infections diagnosis and clinical management. Indian J Med Res 139: 195-204.

*Corresponding author: André L.S. Santos, Laboratório de Investigação de Peptidases (LIP), Departamento de Microbiologia Geral, Instituto de Microbiologia Paulo de Góes (IMPG), Bloco E - subsolo, sala 05, Centro de Ciências da Saúde (CCS), Universidade Federal do Rio de Janeiro (UFRJ), Rio de Janeiro, RJ 21941-902, Brazil, Tel: +55 21 3938 6740; E-mail: andre@micro.ufrj.br

Received December 28, 2015; Accepted December 30, 2015; Published December 31, 2015

Citation: Santos ALS (2015) Perspectives to Combat Microbial Resistance. J Antimicro 1: 106. doi:10.4172/2472-1212.1000106

Copyright: (c) 2015 Santos ALS. This is an open-access article distributed unde the terms of the Creative Commons Attribution License, which permits unrestricted use, distribution, and reproduction in any medium, provided the original author and source are credited. 
7. Uchil RR, Kohli GS, Katekhaye VM, Swami OC (2014) Strategies to combat antimicrobial resistance. J Clin Diagn Res 8: ME01-04

8. Dik JW, Vemer P, Friedrich AW, Hendrix R, Lo-Ten-Foe JR, et al. (2015) Financial evaluations of antibiotic stewardship programs-a systematic review. Front Microbiol 6: 317.

9. Wawruch M, Bozekova L, Krcmery S, Kriska M (2002) Risks of antibiotic treatment. BratisI Lek Listy 103: 270-275.

10. Muñoz P, Valerio M (2015) Antifungal stewardship in daily practice and health economic implications. Mycoses 58 Suppl 2: 14-25.

11. Alcazar-Fuoli L, Mellado E (2014) Current status of antifungal resistance and its impact on clinical practice. Br J Haematol 166: 471-484.

12. WHO - World Health Organization (2014) Antimicrobial resistance global report on surveillance, World Health Organization, Geneva, Switzerland.

13. Burns J (2014) Do health plans have a role in limiting antibiotic resistance? Manag Care 23: 26-30, 32-3.

14. Cars O, Hedin A, Heddini A (2011) The global need for effective antibioticsmoving towards concerted action. Drug Resist Updat 14: 68-69.

15. Pieren M, Tigges M (2012) Adjuvant strategies for potentiation of antibiotics to overcome antimicrobial resistance. Curr Opin Pharmacol 12: 551-555.

16. Schäberle TF, Hack IM (2014) Overcoming the current deadlock in antibiotic research. Trends Microbiol 22: 165-167.

17. Beckham KS, Roe AJ (2014) From screen to target: insights and approaches for the development of anti-virulence compounds. Front Cell Infect Microbiol 4: 139

18. Brown SP, Cornforth DM, Mideo N (2012) Evolution of virulence in opportunistic pathogens: generalism, plasticity, and control. Trends Microbiol 20: 336-342.

19. Clatworthy AE, Pierson E, Hung DT (2007) Targeting virulence: a new paradigm for antimicrobial therapy. Nat Chem Biol 3: 541-548.

20. Allen RC, Popat R, Diggle SP, Brown SP (2014) Targeting virulence: can we make evolution-proof drugs? Nat Rev Microbiol 12: 300-308.

21. Escaich S (2010) Novel agents to inhibit microbial virulence and pathogenicity Expert Opin Ther Pat 20: 1401-1418.

22. Ene IV, Brunke S, Brown AJ, Hube B (2014) Metabolism in fungal pathogenesis. Cold Spring Harb Perspect Med 4: a019695.

23. Fischbach MA (2011) Combination therapies for combating antimicrobia resistance. Curr Opin Microbiol 14: 519-523.

24. Santos ALS, Branquinha MH, d'Avila-Levy CM, Kneipp LF, Sodre CL (2015) Editorial: New Antimicrobial Therapeutics. Curr Med Chem 22: 2112-2115.

25. Santos ALS (2011) Protease expression by microorganisms and its relevance to crucial physiological/pathological events. World J Biol Chem 2: 48-58.

26. Santos ALS, Sodré CL, Branquinha MH, d'Avila-Levy CM (2013) Proteolytic inhibitors: implications on microorganisms development, virulence and pathogenesis. Curr Med Chem 20: 3035-3040

27. Santos ALS (2010) HIV aspartyl protease inhibitors as promising compounds against Candida albicans. World J Biol Chem 1: 21-30.

28. Santos ALS (2011) Aspartic proteases of human pathogenic fungi are prospective targets for the generation of novel and effective antifungal inhibitors. Curr Enz Inhib 7: 96-118.

29. Santos LO, Garcia-Gomes AS, Catanho M, Sodre CL, Santos ALS, et al. (2013) Aspartic peptidases of human pathogenic trypanosomatids: perspectives and trends for chemotherapy. Curr Med Chem 20: 3116-3133.

30. Santos ALS, Braga-Silva LA, Silva BA, Palmeira VF, Valle RS, et al. (2013) Aspartic proteolytic inhibitors induce cellular and biochemical alterations in fungal cells. Chapter 7. In: Naranjan S. Dhalla, Sajal Chakraborti (Eds) Proteases in Health and Disease. Springer, Advances in Biochemistry in Health and Disease 7: 89-119.

31. Santos ALS (2010) Aspartic peptidase inhibitors as potential bioactive pharmacological compounds against human fungal pathogens. Chapter 13 In: Ahmad I, Owais M, Shahid M, Aqil F (eds) Combating fungal infections: problems and remedy, Springer - Verlag, Germany, 289-326
32. Santos ALS, Braga-Silva LA (2013) Aspartic protease inhibitors: effective drugs against the human fungal pathogen Candida albicans. Mini-Rev Med Chem 13: $155-162$.

33. Braga-Silva LA, Santos ALS (2011) Aspartic protease inhibitors as potential anti-Candida albicans drugs: impacts on fungal biology, virulence and pathogenesis. Curr Med Chem 18: 2401-2419.

34. Braga-Silva LA, Mogami SS, Valle RS, Silva-Neto ID, Santos ALS (2010) Multiple effects of amprenavir against Candida albicans. FEMS Yeast Res 10 221-224.

35. Ziccardia M, Souza LOP, Gandra RM, Galdino ACM, Baptista ARS, et al. (2015) Candida parapsilosis (sensu lato) isolated from hospitals located in the Southeast of Brazil: species distribution, antifungal susceptibility and virulence attributes. Int J Med Microbiol 305: 848-859.

36. Abi-chacra EA, Souza LOP, Cruz LP, Braga-Silva LA, Gonçalves DS, et al. (2013) Phenotypic properties associated to virulence from clinical isolates belonging to the Candida parapsilosis complex. FEMS Yeast Res 13: 831-848.

37. Palmeira VF, Kneipp LF, Rozental S, Alviano CS, Santos ALS (2008) Beneficial effects of HIV aspartyl peptidase inhibitors on Fonsecaea pedrosoi: promising compounds to arrest key fungal biological processes and virulence. PLoS ONE 3: e3382.

38. Palmeira VF, Kneipp LF, Alviano CS, Santos ALS (2006) Secretory asparty peptidase activity from mycelia of the human fungal pathogen Fonsecaea pedrosoi: effect of HIV aspartyl proteolytic inhibitors. Res Microbiol 157: 819826.

39. Palmeira VF, Kneipp LF, Alviano CS, Santos ALS (2006) The major chromoblastomycosis fungal pathogen, Fonsecaea pedrosoi, extracellularly releases proteolytic enzymes whose expression is modulated by culture medium composition: implications on the fungal development and cleavage of key's host structures. FEMS Immunol Med Microbiol 46: 21-29.

40. Sangenito LS, Gonçalves KC, Abi-Chacra EA, Sodré CL, d'Avila-Levy CM, et al. (2012) Multiple effects of pepstatin A on Trypanosoma cruzi epimastigote forms. Parasitol Res 110: 2533-2540.

41. Sangenito LS, Menna-Barreto RF, D Avila-Levy CM, Santos ALS, Branquinha MH (2014) Decoding the anti-Trypanosoma cruzi action of HIV peptidase inhibitors using epimastigotes as a model. PLoS One 9: e113957.

42. Santos LO, Vitório BS, Branquinha MH, Pedrozo C, Santos ALS, et al. (2013) Nelfinavir is effective in inhibiting the multiplication and aspartic peptidase activity of Leishmania species, including strains obtained from HIV-positive patients. J Antimicrob Chemother 68: 348-353.

43. Santos LO, Marinho FA, Altoé EF, Vitório BS, Alves CR, et al. (2009) HIV aspartyl peptidase inhibitors interfere with cellular proliferation, ultrastructure and macrophage infection of Leishmania amazonensis. PLoS One 4: e4918.

44. McCann M, KellettA, Kavanagh K, Devereux M, Santos ALS (2012) Deciphering the antimicrobial activity of phenanthroline chelators. Curr Med Chem 19: 2703 2714

45. Santos ALS, Sodré CL, Valle RS, Silva BA, Abi-chacra EA, et al. (2012) Antimicrobial action of chelating agents: repercussions on the microorganism development, virulence and pathogenesis. Curr Med Chem 19: 2715-2737.

46. McCann M, Santos ALS, Silva BA, Romanos MTV, Pyrrho AS, et al. (2012) In vitro and in vivo studies into the biological activities of 1,10-phenanthroline 1,10-phenanthroline-5,6-dione and its copper(II) and silver(I) complexes. Toxicol Res 1: 47-54.

47. McQuitty RJ (2014) Metal-based drugs. Sci Prog 97: 1-19.

48. Mjos KD, Orvig C (2014) Metallodrugs in medicinal inorganic chemistry. Chem Rev 114: 4540-4563

49. Navarro M, Gabbiani C, Messori L, Gambino D (2010) Metal-based drugs for malaria, trypanosomiasis and leishmaniasis: recent achievements and perspectives. Drug Discov Today 15: 1060-1068.

50. Viganor L, Galdino ACM, Nunes APF, Santos KRN, Branquinha MH, et al. (2016) Anti-Pseudomonas aeruginosa activity of 1,10-phenanthrolinebased drugs against both planktonic- and biofilm-growing cells. J Antimicrob Chemother 71: 128-134. 